\title{
OPTIMAL CONTROL TO A FACULTATIVE MUTUALISTIC MODEL WITH HARVESTING
}

\author{
LIANCHENG WANG AND MIN WANG
}

Abstract. In this article, we propose a general facultative mutualistic model with harvesting and investigate an associated optimal control problem. The sufficient and the necessary conditions for the existence of the optimal control are studied. Numerical simulations are carried out to show the efficiency of the proposed control.

Mathematics subject classification (2010): 49K15, 49J15, 92D40.

Keywords and phrases: Optimal control, mutualism, facultative, harvesting.

\section{REFERENCES}

[1] S. Anita, V. Arnǎutu, And V. Capasso, An Introduction to Optimal Control Problems in Life Sciences and Economics, Birkhäuser, 2011.

[2] M. Athans And P. L. Falb, Optimal Control: An Introduction to the Theory and Its Applications, McGraw-Hill, 1966.

[3] S. K. ChatTOPADHYAY, Harvesting on facultative mutualist prey species in presence of a predator, Applied Science and Innovative Research 1 (2017), 1-16.

[4] E. A. Coddington And N. Levinson, Theory of Ordinary Differential Equations, McGraw-Hill, 1984.

[5] W. Ding And G. F. WebB, Optimal control applied to community-acquired methicillin-resistant Staphylococcus aureus in hospitals, Journal of Biological Dynamics 11:sup1 (2017), 65-78.

[6] O. G. Gaoue, J. Jiang, W. Ding, F. B. Agusto, and S. Lenhart, Optimal harvesting strategies for timber and non-timberforest products in tropical ecosystems, Theoretical Ecology 9 (2016), 287297.

[7] P. Georgescu And H. Zhang, Lyapunov functionals for two-species mutualisms, Applied Mathematics and Computation 226 (2014), 754-764.

[8] P. GeOrgescu, H. ZHANG AND D. MAXIN, The global stability of coexisting equilibria for three models of mutualism, Mathematical Biosciences and Engineering 13 (2016), 101-118.

[9] J. N. Holland AND D. L. DeAngelis, Consumer-resource theory predicts dynamic transitions between outcomes of interspecific interactions, Ecology Letters 12 (2009), 1357-1366.

[10] J. N. Holland AND D. L. DeAngelis, A consumer-resource approach to the density-dependent population dynamics of mutualism, Ecology 91 2010, 1286-1295.

[11] H. Joshi, S. LenharT, M. LI, AND L. WANG, Optimal control methods applied to disease models, Contemporary Mathematics 410 (2006), 187-207.

[12] T. LEGOVIĆ AND S. GEČEK, Impact of maximum sustainable yield on mutualistic communities, Ecological Modelling 230 (2012) 63-72.

[13] D. Maxin, P. Georgescu, L. Sega, And L. Berec, Global stability of the coexistence equilibrium for a general class of models of facultative mutualism, Journal of Biological Dynamics 11 (2017), 339-364.

[14] H. V. Moeller AND M. G. Neubert, Multiple friends with benefits: an optimal mutualist management strategy?, The american naturalist 187 (1) (2016), E1-E12.

[15] S. Paul, D. Jana, S. P. Mondal and P. Bhattacharya, Optimal harvesting of two species mutualism model with interval parameters, Journal of Intelligent \& Fuzzy Systems 33 (2017) 19912005, DOI:10.3233/JIFS-161186, IOS Press, 1991. 
[16] C. VARGAS-DE-LEÓn, Lyapunov functions for two-species cooperative systems, Applied Mathematics and Computation 219 (2012), 2493-2497.

[17] D. P. VÁzQuez, R. RAmos-Jiliberto, P. URbani, AND F. S. VAldovinos, A conceptual framework for studying the strength of plant-animal mutualistic interactions, Ecology Letter 18 (2015), 385-400.

[18] W. Walter, Ordinary Differential Equations, Springer-Verlag New York, 1998.

[19] Wikipedia Contributors, Mutualism (BIOlOGY), Wikipedia, The Free Encyclopedia, https://en.wikipedia.org/w/index.php?title=Mutualism_(biology)\&oldid=868338198 (last visited Nov. 18, 2018).

[20] Y. Wu, X. Sun, W. WAng And T. Shen, Policy iteration approach to average optimal control problems for boolean control networks, 2017 36th Chinese Control Conference (CCC) (2017), 79907995. 